\title{
Front Matter: Volume 7936
}

, "Front Matter: Volume 7936," Proc. SPIE 7936, RF and Millimeter-Wave Photonics, 793601 (20 April 2011); doi: 10.1117/12.894840

SPIE. Event: SPIE OPTO, 2011, San Francisco, California, United States 


\title{
PROCEEDINGS OF SPIE
}

\section{RF and Millimeter-Wave Photonics}

\author{
Robert L. Nelson \\ Dennis W. Prather \\ Christopher A. Schuetz \\ Editors
}

23 January 2011

San Francisco, California, United States

Sponsored and Published by

SPIE 
The papers included in this volume were part of the technical conference cited on the cover and title page. Papers were selected and subject to review by the editors and conference program committee. Some conference presentations may not be available for publication. The papers published in these proceedings reflect the work and thoughts of the authors and are published herein as submitted. The publisher is not responsible for the validity of the information or for any outcomes resulting from reliance thereon.

Please use the following format to cite material from this book:

Author(s), "Title of Paper," in RF and Millimeter-Wave Photonics, edited by Robert L. Nelson, Dennis W. Prather, Christopher A. Schuetz, Proceedings of SPIE Vol. 7936 (SPIE, Bellingham, WA, 2011) Article CID Number.

ISSN 0277-786X

ISBN 9780819484734

Published by

SPIE

P.O. Box 10, Bellingham, Washington 98227-0010 USA

Telephone +1 3606763290 (Pacific Time) · Fax +1 3606471445

SPIE.org

Copyright (@ 2011, Society of Photo-Optical Instrumentation Engineers

Copying of material in this book for internal or personal use, or for the internal or personal use of specific clients, beyond the fair use provisions granted by the U.S. Copyright Law is authorized by SPIE subject to payment of copying fees. The Transactional Reporting Service base fee for this volume is $\$ 18.00$ per article (or portion thereof), which should be paid directly to the Copyright Clearance Center (CCC), 222 Rosewood Drive, Danvers, MA 01923. Payment may also be made electronically through CCC Online at copyright.com. Other copying for republication, resale, advertising or promotion, or any form of systematic or multiple reproduction of any material in this book is prohibited except with permission in writing from the publisher. The CCC fee code is 0277-786X/11/\$18.00.

Printed in the United States of America.

Publication of record for individual papers is online in the SPIE Digital Library.

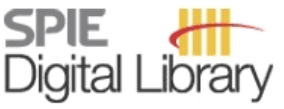

SPIEDigitalLibrary.org

Paper Numbering: Proceedings of SPIE follow an e-First publication model, with papers published first online and then in print and on CD-ROM. Papers are published as they are submitted and meet publication criteria. A unique, consistent, permanent citation identifier (CID) number is assigned to each article at the time of the first publication. Utilization of CIDs allows articles to be fully citable as soon they are published online, and connects the same identifier to all online, print, and electronic versions of the publication. SPIE uses a six-digit CID article numbering system in which:

- The first four digits correspond to the SPIE volume number.

- The last two digits indicate publication order within the volume using a Base 36 numbering system employing both numerals and letters. These two-number sets start with 00, 01, 02, 03, 04 , 05, 06, 07, 08, 09, OA, OB ... 0Z, followed by 10-1Z, 20-2Z, etc.

The CID number appears on each page of the manuscript. The complete citation is used on the first page, and an abbreviated version on subsequent pages. Numbers in the index correspond to the last two digits of the six-digit CID number. 


\section{Contents}

$\checkmark$ Conference Committee

\section{SESSION 1 COMPONENTS AND MATERIALS}

793603 Full wave analysis of structural resonances in composite right/left-handed leaky wave antenna [7936-02]

H. Zhou, National Institute for Materials Science (Japan); K. Sakoda, National Institute for Materials Science (Japan) and Univ. of Tsukuba (Japan)

793604 Phase shifter using carbon nanotube thin-film transistor for flexible phased-array antenna [7936-03]

D. Pham, The Univ. of Texas at Austin (United States); H. Subbaraman, Omega Optics, Inc. (United States); M. Y. Chen, Texas State Univ., San Marcos (United States); X. Xu, R. T. Chen, The Univ. of Texas at Austin (United States)

\section{SESSION 2 SOURCES AND MODULATORS I}

793607 High speed electro-optic polymer phase modulator using an in-plane slotline RF waveguide [7936-07]

D. H. Park, Y. Leng, Univ. of Maryland, College Park (United States); J. Luo, A. K.-Y. Jen, Univ. of Washington (United States); W. N. Herman, Univ. of Maryland, College Park (United States)

\section{SESSION 3 SOURCES AND MODULATORS II}

793608 Recent progress toward a nanoslot modulator: polymer poling experiments [7936-08] Y. S. Lee, S. Takahashi, H. Mahalingam, W. H. Steier, The Univ. of Southern California (United States); G. E. Betts, J. X. Chen, Photonic Systems, Inc. (United States)

793609 High-frequency microwave signal generation in a semiconductor laser under double injection locking [7936-09]

Y.-C. Chen, Y.-S. Juan, F.-Y. Lin, National Tsing Hua Univ. (Taiwan)

7936 OA Fiber ring resonator based opto-electronic oscillator: phase noise optimisation and thermal stability study [7936-10]

K. Saleh, Lab. d'Analyse et d'Architecture des Systèmes, CNRS (France), Univ. de Toulouse (France) and Ctr. National d'Études Spatiales (France); A. Bouchier, P. H. Merrer, O. Llopis, Lab. d'Analyse et d'Architecture des Systèmes, CNRS (France) and Univ. de Toulouse (France); G. Cibiel, Ctr. National d'Études Spatiales (France)

7936 OB Compact optoelectronic oscillator using whispering gallery mode resonators for radio-frequency and millimeter wave generation [7936-11] K. Volyanskiy, P. Salzenstein, H. Tavernier, Institut FEMTO-ST, CNRS (France); M. Pogurmirskiy, Saint-Petersburg State Univ. of Information Technologies, Mechanics and Optics (Russian Federation); Y. K. Chembo, L. Larger, Institut FEMTO-ST, CNRS (France) 
7936 OC Poling study of electro-optic polymers in silicon slot waveguides [7936-12] A. Szep, Air Force Research Lab. (United States); A. Chen, Univ. of Washington (United States); S. Shi, Univ. of Delaware (United States); Z. Lin, Air Force Research Lab. (United States); D. Abeysinghe, Univ. of Cincinnati (United States)

\section{SESSION 4 SENSORS/RECEIVERS}

7936 OD Progress in millimeter-wave imaging (Invited Paper) [7936-13]

D. A. Wikner, U.S. Army Research Lab. (United States)

7936 OE Design and construction of an electro-optic RF metamaterial array (Invited Paper) [7936-14]

W. Chen, Univ. of Dayton (United States); R. L. Nelson, Air Force Research Lab.

(United States); Q. Zhan, Univ. of Dayton (United States)

7936 OF ACP-OPLL photonic integrated circuit for high dynamic range RF/photonic links [7936-15] Y. Li, Univ. of Massachusetts Dartmouth (United States); A. Bhardwaj, L. Coldren, J. Bowers, Univ. of California, Santa Barbara (United States); P. Herczfeld, Drexel Univ. (United States)

\section{SESSION 5 SYSTEMS}

$7936 \mathrm{OH}$ Design of a 10-Gb/s satellite downlink at millimeter-wave frequencies (Invited Paper) [7936-17]

R. W. Ridgway, D. W. Nippa, S. Yen, T. J. Barnum, Battelle Memorial Institute (United States)

7936 Ol Design of a millimeter-wave full-Stokes polarimeter utilizing optical up-conversion [7936-18] J. P. Wilson, Univ. of Delaware (United States); C. A. Schuetz, R. D. Martin, T. E. Dillon, P. Yao, Phase Sensitive Innovations, Inc. (United States); D. W. Prather, Univ. of Delaware (United States)

7936 OK Millimeter wave image processing through point spread function engineering [7936-20] J. N. Mait, U.S. Army Research Lab. (United States); R. D. Martin, C. A. Schuetz, Phase Sensitive Innovations (United States); D. W. Prather, Univ. of Delaware (United States)

7936 OL Phase modulated radio-over-fiber link with electro-optic downconversion using a delay-line interferometer (Invited Paper) [7936-21]

T. E. Murphy, Univ. of Maryland, College Park (United States); V. R. Pagán, Lab. for Physical Sciences (United States)

7936 OM Novel WDM to OTDM wavelength conversion system for transmission of discrete sampling spectrum in single wavelength channel [7936-22]

T. Yang, C. Wang, J. Wang, C. Ge, M. Sang, Tianjin Univ. (China)

Author Index 


\title{
Conference Committee
}

\author{
Symposium Chair
}

Liang-Chy Chien, Kent State University (United States)

Symposium Cochairs

Klaus P. Streubel, OSRAM GmbH (Germany)

E. Fred Schubert, Rensselaer Polytechnic Institute (United States)

Program Track Chair

James G. Grote, Air Force Research Laboratory (United States)

Conference Chairs

Robert L. Nelson, Air Force Research Laboratory (United States)

Dennis W. Prather, University of Delaware (United States)

Christopher A. Schuetz, Phase Sensitive Innovations, Inc. (United States)

Program Committee

Glenn D. Boreman, CREOL, The College of Optics and Photonics, University of Central Florida (United States)

Ray T. Chen, The University of Texas at Austin (United States)

Charles H. Cox III, Photonic Systems Inc. (United States)

Larry R. Dalton, University of Washington (United States)

Ronald Esman, Defense Advanced Research Projects Agency

(United States)

Yeshaiahu Fainman, University of California, San Diego (United States)

Peter R. Herczfeld, Drexel University (United States)

Warren N. Herman, University of Maryland, College Park (United States)

Michael Hochberg, University of Washington (United States)

Yeifi Li, University of Massachusetts Dartmouth (United States)

Joseph N. Mait, U.S. Army Research Laboratory (United States)

Mark S. Mirotznik, University of Delaware (United States)

Robert A. Norwood, College of Optical Sciences, The University of Arizona (United States)

Gernot S. Pomrenke, Air Force Office of Scientific Research (United States)

Attila A. Szep, Air Force Research Laboratory (United States)

Keith I. Williams, U.S. Naval Research Laboratory (United States)

Qiwen Zhan, University of Dayton (United States) 
Session Chairs

1 Components and Materials

Christopher A. Schuetz, Phase Sensitive Innovations, Inc. (United States)

2 Sources and Modulators I

Shouyuan Shi, University of Delaware (United States)

3 Sources and Modulators II

Shouyuan Shi, University of Delaware (United States)

4 Sensors/Receivers

Dennis W. Prather, University of Delaware (United States)

5 Systems

Robert L. Nelson, Air Force Research Laboratory (United States) 